\title{
Śmierć żuczka in flagranti* (Bajka o królewnie, której nie było Marka Krystiana Emanuela Baczewskiego)
}

\author{
The Death of a Little Beetle in flagranti \\ (Bajka o królewnie, której nie było / A Fairy Tale about the Princess \\ who Was Not There by Marek Krystian Emanuel Baczewski)
}

Summary: The aim of this article is an attempt to incorporate the works by Marek Krystian Emanuel Baczewski - a modern writer and poet - into the framework of a lesson, and to present an idea for an interpretation one of his short stories. The author presents the new ways of reading the text by Baczewski through linking up the microscale perspective with zoocentric perspective.

The micrological gesture is the prelude to considerations in the spirit of animal studies. This way of thinking may be conducive to broadening the students' skills of perception. Teaching young people to pay attention to details can be also a good experiment. They can be taught that literature is not a one-dimensional subject and that the text can be reinterpreted in many different ways.

Key words: micrology, animal studies, interpretation, didactic

* Pomysł na tytuł niniejszego artykułu inspirowany jest fragmentem pracy Katarzyny Trzeciak. Autorka pyta w nim, odwołując się do jednego z wywiadów Tadeusza Kantora: „Co znaczy, że artysta łapie przedmiot in flagranti?”. Dla moich rozważań ważna będzie odpowiedź Kantora: „Moim celem w sztuce, zasadniczym motywem mojej twórczości jest »odzyskanie« przedmiotu, odnalezienie kontaktu z realnością [...]. Trzeba je użyć w sposób specjalny, niezgodny z jego masową wszechobecną funkcją. [...] Złapać in flagranti, wpleść w pewną czynność bezinteresownie”. Cyt. za: K. Trzeciak: Buty Heideggera i wraki Kantora. O potrzebie czytania tekstów ,trudnych" w szkole. W: Doświadczenie lektury. Między krytyka literacka a dydaktyka literatury. Red. K. Biedrzycki, A. Janus-Sitarz. Kraków 2012, s. 254. Myślę, że w tzw. tekstach trudnych, określanych jako hermetyczne, kryje się właśnie ta bezinteresowność, która może być odbierana intuicyjnie, metaforycznie, przez każdego odbiorcę, także czytelnika nieprofesjonalnego. 
Na lekcjach języka polskiego wciąż czyta się niewiele literatury najnowszej. Gdy tymczasem: „Nikt nie wyobraża sobie nauczania biologii, chemii czy fizyki bez pokazania uczniom najnowszych osiągnięć z dziedziny genetyki czy fizyki jądrowej"”. W nowo uchwalonej podstawie programowej dla szkół podstawowych $^{2}$ i ponadpodstawowych ${ }^{3}$ nie ma zapisów obligujących nauczycieli do pracy z literaturą XXI wieku (prowadzący zajęcia może dobrać sobie kilka pozycji nieobowiązkowych). Wiadomo, że na szkolnej liście lektur najwięcej miejsca będzie zajmowała literatura klasyczna (większość ludzi zetknie się z nią tylko na lekcji polskiego), ale korzyści takiego poszerzania, uzupełniania kanonu są decydujące. Zdaniem Marty Rusek dla wytworzenia więzi uczeń-nauczyciel, a nawet uczeń-literatura:

Jeżeli omawiamy teksty kanoniczne, które są „obrośnięte” kanonicznymi odczytaniami, nauczyciel zawsze staje w pozycji znawcy. W przypadku tekstów nieutrwalonych w szkolnej dydaktyce nauczyciel staje przed szansą, żeby być też świadkiem lektury i pokazać, że czytanie literatury jest po prostu ważne dla życia ${ }^{4}$.

Moja propozycja naprawy tego stanu rzeczy to spotkanie z książką śląskiego autora; urodzonego w Bielawie, mieszkającego w Zawierciu. Marek Krystian Emanuel Baczewski to pisarz tajemniczy, chowający się za oryginalnym pseudonimem (nazywa się Marek Kowalik) i oszczędną autocharakterystyką: „niezależny asceta”. Pominięty przez krytykę literacką lat dziewięćdziesiątych

${ }^{1}$ Wstęp. W: Nowe odsłony klasyki w szkole. Red. E. Jaskółowa, K. Jędrych. Katowice 2013, s. 7.

${ }^{2}$ Podstawa programowa - język polski - szkoła podstawowa - klasy IV-VIII. Załącznik $\mathrm{nr} 2$ do Rozporzadzenia MEN z 14.02.2017 r. w sprawie podstawy programowej wychowania przedszkolnego oraz podstawy programowej kształcenia ogólnego dla szkoły podstawowej, $w$ tym dla uczniów z niepetnosprawnością intelektualna $w$ stopniu umiarkowanym lub znacznym, kształcenia ogólnego dla branżowej szkoły I stopnia, kształcenia ogólnego dla szkoły specjalnej przysposabiającej do pracy oraz kształcenia ogólnego dla szkoły policealnej. https://men.gov.pl/ wp-content/uploads/2016/11/podstawa-programowa-\%E2\%80\%93-jezyk-polski-\%E2\%80\%93-szkola-podstawowa-\%E2\%80\%93-klasy-iv-viii-.pdf [data dostępu: 17.01.2018].

3 Podstawa programowa kształcenia ogólnego dla czteroletniego liceum ogólnokształcacego i pięcioletniego technikum. Załącznik nr 1 do Rozporzadzenia MEN z 30.01.2018 r. w sprawie podstawy programowej kształcenia ogólnego dla liceum ogólnokształcacego, technikum oraz branżowej szkoły II stopnia, wchodzącego w życie 1.09.2019 r. https://men.gov.pl/wp-content/ uploads/2018/01/zalacznik-nr-1.pdf [data dostępu: 17.01.2018].

${ }^{4} C z y(m)$ zastapić Orzeszkową? Debata o stanie nauczania literatury wspótczesnej $w$ szkołach. http://fragile.net.pl/home/czym-zastapic-orzeszkowa-debata-o-stanie-nauczania-literatury-wspolczesnej-w-szkolach/ [data dostępu: 17.01.2018].

${ }_{5}$ Tak sam siebie sportretował autor przy okazji wydania debiutanckiego tomu Fortepian Baczewskiego, co później tłumaczył w wywiadzie dla portalu internetowego tak: ,jak wspomniałeś, na tejże okładce — ja napisałem. Co do innych książek — nie ja pisałem tam notki biograficzne. 
XX wieku jest obecnie poetą przemilczanym 6 , a jego twórczość sytuuje się na marginesie badań literaturoznawczych ${ }^{7}$. Szkoda, bo jak dowodzi Dawid Kujawa: ,prawdopodobnie Baczewski to największy erudyta spośród aktywnych dziś polskich poetów [...]”, tworzący „literaturę, która współgra z postnowoczesnym obrazem świata [...]".

Utwory autora Antologii wierszy nieśmiatych przy pierwszej lekturze stawiają opór, nie poddając się łatwo eksplikacji. Nie powinien to być powód odrzucenia jego dorobku przez nauczyciela przygotowującego lekcję. Katarzyna Trzeciak poświęciła tej problematycznej kwestii artykuł Buty Heideggera $i$ wraki Kantora. O potrzebie czytania tekstów ,trudnych” w szkole, w którym przekonuje:

budowanie relacji z tekstem nie zawsze musi mieć swój fundament w prostym i jasnym przekazie. Ten bowiem jest raczej formą uspokojenia. Potrzebnego, lecz nie wystarczającego w starciu z nie zawsze ułożoną rzeczywistością, także rzeczywistością sztuki, która wysyła do swoich odbiorców sygnały obcości i niezrozumiałości ${ }^{9}$.

Badaczka (podążając za przemyśleniami Anny Janus-Sitarz i Krystyny Koziołek) zakwestionowała konieczność formułowania sensów przy każdorazowej próbie interpretacji, ponieważ, krótko mówiąc, taka stała praktyka sprowadza działania nauczyciela i ucznia do mechanicznych czynności, a przez to z kolei świat, oglądany z perspektywy literatury, traci na swej złożoności. Młody odbiorca, dzięki włączeniu dzieł najnowszych w jego edukację, ma szansę do-

Dodam jeszcze, że wizerunek Ascety pojawił się z kolei na okładce Nieśmiałych. Dopiero jednak na okładce Morza pojawiła się notka dokładnie taka, jak chciałem, to znaczy — nieobecność notki. W sumie uważam, że biografie na okładkach książek to idiotyzm. Mam nadzieję, że co do istoty samego terminu: »Niezależny asceta« — nie będę musiał produkować dodatkowych komentarzy. Jego istotą jest prostolinijna dosłowność. Często bywam niezależny od samego siebie. No comments, jak to niegdyś pisano na rysunkach satyrycznych". Zob. Być w nadziei (rozmowa z Markiem Krystianem Emanuelem Baczewskim). http://www.literaturajestsexy.pl/byc-w-nadziei-rozmowa-z-markiem-krystianem-emanuelem-baczewskim/ [data dostępu: 17.01.2018].

${ }^{6}$ Przyczyny tego stanu rzeczy należy upatrywać w czynnikach zewnątrzliterackich. Baczewski został tak potraktowany na skutek przyjętego uproszczonego, binarnego podziału literatury na „linię Sosnowskiego” i „linię Świetlickiego”. Zob. D. Kujawa: „Powiedzmy kolokwialnie, że ja z innej beczki”. Marek Krystian Emanuel Baczewski jako poeta przemilczany. W: Nie w pierwszym szeregu. O poetach lat 90. Red. T. Cieślak, T. Dalasiński. Toruń 2015.

${ }^{7}$ Nie ma jednak tego złego, co by na dobre nie wyszło: tym sposobem pisarz — przekonuje Dawid Kujawa - uprawiając marginesową działalność, staje się wzorowym uczniem Jacques'a Derridy. Zob. Ibidem, s. 20.

${ }^{8}$ Ibidem.

${ }^{9}$ K. Trzeciak: Buty Heideggera i wraki Kantora. O potrzebie czytania tekstów ,trudnych” w szkole. W: Doświadczenie lektury..., s. 256-257. 
świadczyć na sobie samym (eksperymentalnie), że literatura nie jest przedmiotem jednowymiarowym, a tekst podlega ciągłym reinterpretacjom, wymyka się jednoznacznym sensom.

Spośród ,trudnych” tekstów Baczewskiego proponuję lekturę na lekcji jednego z opowiadań: Bajka o królewnie, której nie byto ${ }^{10}$. Utwór pochodzi z tomu Bajki Baczewskiego, wydanego w 2012 roku. Nie chcę odczytywać tej bajki w kontekście jej genologii literackiej ${ }^{11}$ (postmodernistyczne przemieszczenia zapowiada sam tytuł). Intryguje mnie bardziej pewien szczegół tej opowieści, a dokładniej pewna zagadkowa śmierć ukrywająca się w buduarze lektury. Trzeba bowiem wyjaśnić na wstępie, że w tej dość okrutnej bajce ginie tylko jeden bohater: chrząszcz. Wszystko inne (małe czy duże) przetrwa: żyć będzie lub przebywać w niebycie (jak królewna). Spróbuję zatem podjąć się trudu interpretacji tego wycinka świata przedstawionego, nim przystąpię do próby włączenia utworu w poczet lektur szkolnych.

\section{Zwłoki}

Trup chrząszcza ujawniony zostaje w pokoju królewny na toaletce z chińskiej laki (s. 10). Ponieważ śmierć owadzia jest z natury swej ulotna, trudno dostrzegalna, pozwolę sobie uczynić ruch mikrologiczny i ją wyeksponować:

Otwarty słoiczek z resztką zeschniętego, wyblakłego różu posłużył jakiemuś chrząszczowi za miejsce ostatniego spoczynku (s. 10).

Jak tylko odkryte zostało ciało, pojawić się muszą pytania, także te z serii eschatologicznych, wiążących odejście chrząszcza z niebytem królewny: Czy śmierć jest jednym z przejawów nieistnienia? Czy jest podległym mu stanem, a może czymś całkowicie odrębnym? W jakim celu czytelnik ma zobaczyć, dostrzec ten malutki zgon? Ciekawe jest to, że tak jak status królewny jest niepewny (nie wiadomo, czy istnieje, czy nie), tak relacja śmierci z nieistnieniem również jest trudna do określenia. Nieistnienie wydaje się szerszym pojęciem niż sama śmierć - bo można nie istnieć, nigdy się nie narodziwszy. Jednak

${ }^{10}$ Cytaty w całym tekście pochodzą z następującego wydania (i są oznaczone odpowiadającymi im numerami stron): M.K.E. Baczews ki: Bajki Baczewskiego. Katowice 2012.

${ }^{11} \mathrm{~W}$ tę stronę zmierzała recenzja Marty Jaworek. Zob. M. Jaw orek: Baśń, której nie było. „Bajki Baczewskiego” Marka K.E. Baczewskiego. „Inter-. Literatura — Krytyka - Kultura” 2013, nr 1. Publikacja dostępna także online: https://pismointer.files.wordpress.com/2015/04/ inter-2013-nr-11.pdf [data dostępu: 17.01.2018]. 
równocześnie może zastanawiać, czy śmierć jest przejściem w stan nieistnienia, czy też dalszym istnieniem w innej formie. Pytania się mnożą, tymczasem żuczek ,„[...] czeka w progu zaświatów na spóźniający się przelew rzeczywistości, czy też wymyka się obławom akwizytorów doczesnego bytu" (s. 5).

\section{Miejsce zbrodni?}

Gdy przyglądamy się dokładniej miejscu pochówku chrząszcza, uderza nas to, że wygląda jak celowo zainscenizowane:

Komnata, w której nie mieszkała, przesiąkła zapachem jej nieobecności. [...]. Łóżko z adamaszkowym baldachimem stało nieużywane. [...] $\mathrm{Na}$ siedzeniu krzesła leżała pozostawiona robótka ręczna. [...] Safianowe pantofelki o śmiesznych, wąskich noskach wyglądały spod łóżka królewny, przyozdobione kokardką z różowego atłasu. [...] Na sekretarzyku leżał otwarty zeszycik [...]. Na jego nieparzystej, czystej stronie spoczywało pióro z zardzewiałą stalówką (s. 9).

Nie wiadomo nic na temat przyczyn odejścia chrząszcza z tego baśniowego świata. Narracja wydaje się neutralnie milczeć w tym względzie. Sama wiedza o biologii tej gromady utwierdza w przekonaniu, że są to bardzo wytrzymałe zwierzęta. To liczny gatunek, stosunkowo łatwo dostosowujący się do zmiennych warunków otoczenia ${ }^{12}$. Ciało ich pokrywa kutikularny pancerz, który zapewnia im doskonałą ochronę przeciw różnym chemicznym środkom ${ }^{13}$. Wytrzymałość owadów dobrze ilustrują niektóre przypadki. Istnieje pewna grupa gatunków wodnych, które wytrzymują nawet kilka godzin pod wodą i to bez żadnych przerw na wynurzanie (larwy amerykańskiego opuchlaka żyją aż pięć tygodni pod wodą) $)^{14}$. Odkryte zostały również i takie gatunki, które bez wody

12 Znany warszawski entomolog Marek Kozłowski przekonuje, że „Owady to twarde bestie!”, dowodząc, że: „Katastrofa sprzed 65 milionów lat, która zmiotła z powierzchni ziemi dinozaury [...] i prawie wszystkie ssaki, na owadach nie wywarła większego wrażenia" (M. Kozłow ski: Owady Polski. T. 1. Warszawa 2015, s. 9). Badacz przywołuje również znany w środowisku biologów rysunek „ilustrujący hierarchię wielkości w świecie ożywionym”. Na tym schemacie wielkość namalowanego zwierzęcia odpowiada liczbie opisanych przez naukowców gatunków: przedstawiciel ssaków (słoń) był tak mały, że ledwo można go dostrzec schowanego pod kapeluszem grzyba, a reprezentant owadów (chrząszcz) dominuje, zajmując największą cześć obrazka (Ibidem, s. 13).

${ }^{13}$ H. Sandner: Owady. Warszawa 1990, s. 11.

${ }_{14}$ Podaję za: J. Boczek: Człowiek i owady. Warszawa 2001, s. 21-22. 
potrafią przetrwać nawet kilka lat (larwy muchówek) ${ }^{15}$. Dlaczego więc żuczek nie przeżył w komnacie królewny?

\section{Karaluchy, mrówki i pająki}

W poukładanej rzeczywistości, w pokoju królewny, której nie było, wypełniając przestrzeń jej nieistnienia, żyją sobie jeszcze inne owady — karaluchy, mrówki i pająki:

Po parzystej, również nie zapisanej stronie, spacerował karaluch wąsaty niczym halabardnik. [...] Na toaletce z chińskiej laki stało kościane puzderko na puder. Na jego wieczku mrówki faraona urządziły sobie plac do musztry. [...] Sprzątaczki, ku uciesze niezliczonych pająków, nauczyły się omijać ten rewir pałacu (s. 9-10; podkr. — M.P.-L.).

Ich obecność można interpretować różnie. Na nieparzystej stronie zeszyciku (pamiętnika?) królewny znajduje się pióro. Jego zardzewiała stalówka potencjalnie może być wszystkim lub niczym. Pilnujący owej formy, po parzystej stronie, halabardnik-karaluch, staje się jedyną uchwytną treścią: odwrotnością możliwości tworzenia, czystą estetyką chwili. Przez sam fakt pilnowania nadaje wartość owej potencjalnej możliwości. Tymczasem mrówki faraonki, zorganizowane $\mathrm{w}$ formację wojskową, demonstracyjnie okupują bezsilną przestrzeń. Przewaga owadziej siły nadaje charakterystyczny ryt temu miejscu. W takim otoczeniu chrząszcz jawi się jako umierający arystokrata, a być może nawet jako ktoś blisko skoligacony z rodziną królewską (umiera w różu, być może $w$ purpurze, choć wyblakłej). Warto tutaj zatrzymać się i zwrócić uwagę na pewien naukowy fakt:

społeczne owady są w swoich upodobaniach znacznie mniej wyspecjalizowane niż owady samotne. Każdy chrząszcz czy larwa motyla żeruje tylko na jednym rodzaju roślin; każda samotna osa jest wspaniale zaprojektowana do zabijania tylko jednego rodzaju ofiar. Większość mrówek jednak je niemal wszystko, co znajduje się na ich drodze, pszczoły odwiedzają kwiaty wszystkich kształtów itp. ${ }^{16}$

Być może więc owa specjalizacja była przyczyną śmierci chrząszcza, gdyż doczekał takich czasów, w których monarchia czy arystokracja jest coraz mniej

${ }^{15}$ Zob. S.M. Klimaszewski: Świat owadów. Warszawa 1973, s. 49.

16 M. Ridley: O pochodzeniu cnoty. Tłum. M. Koraszewska. Poznań 2000, s. 57. 
potrzebna. A być może jest to pierwsza ofiara pogarszających się warunków do życia w komnacie królewny? Na jednej ze stron internetowych miłośników chrząszczy znaleźć można przepis na przygotowanie pełnowartościowego pokarmu dla żuków, na który składa się papka z banana, miodu i pyłku pszczelego. Niedoświadczonych jeszcze koleopterologów, chcących założyć hodowlę, przestrzega się tam, że dodatek sztucznego miodu powoduje śmierć chrząszcza ${ }^{17}$. Do tego tropu warto jeszcze wrócić.

W tym małym zakątku pałacu starcie pomiędzy cywilizacją a naturą zdaje się skupiać jak w soczewce. Pająki, czające się w komnacie, są swoistą partyzantką małego królestwa opanowanego przez mrówki i karaluchy, co w jakiejś mierze dopełnia obrazu zwycięstwa owadziej siły. Ważne jest także to, kiedy dzieje się ten przewrót:

Uściślijmy czas akcji; jak na bajkę przystało, rzecz dzieje się u schyłku średniowiecza. Trudno byłoby ustalić konkretną datę; ot po prostu któregoś dnia świat odczuł naglącą potrzebę braku królewny (s. 6).

Właśnie pod koniec wieków średnich idea monarchii powoli zaczyna się wyczerpywać, pojawiają się nowe idee nowszej generacji, np. republikanizm. Wydawałoby się więc, że mrówki faraona będą miały problem z nową formułą władzy, jednak jak dowodzą badania, ten gatunek świetnie radzi sobie ze swoją nomadyczną naturą ${ }^{18}$ bez żadnej królowej ${ }^{19}$. Sam fakt nieistnienia może się zatem wiązać - zarówno w wydaniu owadzim, jak i ludzkim - z formułą bezkrólewia (tu w tym szczególnym przypadku: bezkrólewnia). Jest to nie tylko stan fizyczny, ale i duchowy. Wydaje się w tym ostatnim przypadku, że strawa nie tylko fizyczna, ale i duchowa, zaczyna coraz bardziej szkodzić arystokratom (chrząszcz) - duchom wyższym.

\section{Zwierciadło}

Cały ten mikroświat królewskiej komnaty może okazać się tylko odbiciem, jak w jaskini Platona, albowiem:

${ }^{17}$ Blog Hodowla chrząszczy i motyli. http://zibi.entomo.pl/hodowla_chrzaszczy.php [data dostępu: 17.01.2018].

${ }_{18}$ O stopniach kultury mrówek pisał już pod koniec wieku XIX Stanisław Kluczycki. Zob. S. Kluczycki: Mrówki. Szesnaście pogadanek z notatek Stanisława Kluczyckiego. Kraków 1897, s. $29-30$.

${ }^{19}$ Powołuję się na następujące badania: E.O. Wilson: Społeczeństwa owadów. Tłum. D.H. Tymowska. Warszawa 1979, s. 56. 
stare lustro ukazywało wszystkie te przedmioty spowite w mgłę, która odbierała im część realności (s. 10).

Wiedząc o tym, trzeba zadać sobie dodatkowe pytania: czy mgła spowiła odbicie czy rzeczywistość? Być może po drugiej stronie lustra królewna istnieje, a cała odbita rzeczywistość jest jedynie wytworem jej wyobraźni? Status chrząszcza też staje się problematyczny — przeciwieństwem śmierci jest życie. To znaczyłoby, że życie żuka trwa, stał się bowiem nieśmiertelny. Tymczasem pozostała owadzia siła (mrówki, karaluchy i pająki), widziana w odbiciu, byłaby tylko śladem, motywem vanitas. Natomiast współistnienie żuka z królewną pokazuje, że pytanie, które zostało postawione na początku niniejszego wywodu, dotyczące relacji między istnieniem a nieistnieniem, właśnie w odbiciu znalazłoby pozytywny wyraz: jest niemal tym samym.

W nierozstrzygalnym sporze o status królewny (o jej istnienie lub nieistnienie) prawdziwym wydaje się tylko lustro, które potencjalnie umożliwia przybranie formy zarówno istnienia, jak i nieistnienia. Taki status ontyczny (bytowy) człowieka czyni jego życie podobnym do owadziego — jesteśmy w stanie dostrzec zmianę, ruch, ale trudno uchwycić wszystkie cechy bytu.

\section{Sposoby widzenia (garść inspiracji)}

Ów nowoczesny utwór, przechylający się w stronę awangardy, można spróbować zaadaptować do szkolnej interpretacji w ostatnich klasach licealnych. Jak pracować z prozą Baczewskiego? Sugeruję pokazać uczniom sposób działania optyki mikro i makro, narzędzi mikropoetyki, tj. studiów mikrologicznych, których wyniki badań zbierają się przede wszystkim w trzech tomach pod kierownictwem Aleksandra Nawareckiego ${ }^{20}$. Przy tej okazji należy szczególnie pochylić się nad konstatacją Pawła Jędrzejki, który zmianę widoku oglądu tekstu $\mathrm{z}$ makro na mikro nazywa wprost realizacją koła hermeneutycznego ${ }^{21}$. Wspiera

${ }^{20}$ Miniatura i mikrologia literacka. T. 1. Red. A. Nawarecki. Katowice 2000; Miniatura i mikrologia literacka. T. 2. Red. A. Nawarecki. Katowice 2001; Miniatura i mikrologia literacka. T. 3. Red. A. Nawarecki, przy współudziale B. Myty ch. Katowice 2003. Wiedzę na temat mikropoetyki warto pogłębić i sięgnąć po następujące pozycje: A. Naw arecki: Mały Mickiewicz. Studia mikrologiczne. Katowice 2003 oraz Skala mikro w badaniach literackich. Red. A. Nawarecki, M. Bogdanowska. Katowice 2005.

${ }^{21}$ Odsyłam do pełnego wywodu: P. Jędrzejko: Oscylacje literackie, czyli od Gadamera do mikrologicznej krytyki. W: Miniatura i mikrologia literacka. T. 2..., s. 27—57. Trzeba nadmienić, że Aleksander Nawarecki niechętnie przyjmuje tę wersję rozumienia mikrologii (zob. A. Nawarecki: Wstęp. W: Miniatura i mikrologia literacka. T. 2..., s. 8, przypis 1). 
go w tym (trudno rozstrzygnąć, czy świadomie) Aleksandra Kunce, pisząc tak o odkrywaniu mikrokosmosu:

Dyskretny urok mikrologii [...] polega na dostrzeżeniu ulotności i chwili, punktowości każdej całości, a także na znajdowaniu systemowej mocy wiążącej najbardziej niepokorne i marginalne punkty ${ }^{22}$.

Na lekcji, w trakcie lektury Bajek, dobrze jest jednak zdobyć się na odwagę, by przełamać ów interpretacyjny impas, i zmienić pole dyskusji przez włączenie do rozważań praktyk studiów nad zwierzętami (animal studies, human-animal studies), co próbowałam czynić w swojej analizie opowiadania. Na marginesie dodam, że interesujące mogłoby być także podjęcie rozważań na temat relacji między przestrzenią a kulturą, czyli przymiarka do interpretacji geopoetycznej (centrum pogłębionej refleksji mógłby stać się opis nie-miejsca, w którym bywa nieistniejąca królewna).

Prawdopodobnie młodzi odbiorcy, czytając po raz pierwszy opowiadanie, tak skupią się na sugestywnym tytule (zwłaszcza, że odwołuje się on do dobrze znanego im gatunku literackiego, jakim jest baśń), że niejako automatycznie będą ćwiczyli się w postrzeganiu makro ${ }^{23}$, koncentrując się na losach nieistniejącej królewny ${ }^{24}$. Recepcji tekstu nie powinny poprzedzać żadne dodatkowe przygotowania $^{25}$. Nauczyciel będzie wykorzystywał tutaj pewną bezwładność odczytu. Można jedynie poprosić uczniów, aby zapisywali swoje przemyślenia, by wzmocnić przekonanie młodzieży o ważności pierwszych rozpoznań. Najlepiej zaproponować przeczytanie tego utworu w domu. Następnie, podczas lekcji, celem szczególnej uwagi należy uczynić fragment, w którym mowa jest o sypialni dziewczyny. Tym razem jednak nauczyciel powinien zadać pytanie, które pomoże ujrzeć małą śmierć chrząszcza: Kto zaginąl, a kto zginąl w tej bajce? Rozejrzyj się dobrze po komnacie królewny i spróbuj odpowiedzieć.

Wskazanie dwóch bohaterów fabuły zbuduje dwa ośrodki, wokół których będą oscylowały klasowe interpretacje. Jedna, stawiająca w centrum rozważań nieistniejąca królewnę — to linia rozważań w ujęciu makro. Druga, której środkiem jest chrząszcz — to rozważania w ujęciu mikro. Dzięki dostrzeżeniu

${ }^{22}$ A. Kunce: $O$ motylu i dyskretnym uroku mikrologii. W: Skala mikro w badaniach literackich..., s. 44. Podkr. - M.P.-L.

${ }^{23} \mathrm{~W}$ przypadku tego opowiadania interpretacja w ujęciu makro nie jest taka prosta. Do zadanych wcześniej trzeba by dodać pytanie o to, czy nieistniejąca księżniczka jest ideą, czy może jest tą formą bytu, która nie istnieje; czy może jest reprezentantką statystycznej królewny (opisanym poetycko zjawiskiem socjologicznym lub psychologicznym). Baczewski jak zwykle wymyka się jednoznacznościom.

${ }^{24}$ Używając nomenklatury animal studies: w ujęciu antropocentrycznym.

${ }^{25}$ Specyficzną sytuacją motywacyjno-problemową będzie zderzenie odczytu niekierowanego z odczytem ukierunkowanym przez nauczyciela. Dzięki ingerencji nauczyciela uczeń może zobaczyć (!) więcej. 
małego żuka w tkance tekstowej Bajki dokonuje się poszerzenie pola obserwacji uczniowskiej, ale nie tylko świata przedstawionego. Zdaniem mikrologa Nawareckiego czytanie szczegółowe ma dalekosiężne skutki: „skupienie na graficznym, morfologicznym czy stylistycznym detalu [...] otwiera oczy na świat, nie tylko literatury" 26 .

Następnym krokiem jest przejście do zadań pomagających w przyjęciu perspektywy zoocentrycznej. Poświęcenie chwili na lekcji na wyszukanie informacji na temat owadów, zwłaszcza chrząszczy, pomoże w budowaniu rozgałęzień interpretacyjnych ${ }^{27}$. Co uczniowie mogą znaleźć w książkach z koleopterologii? Mogliby się np. dowiedzieć, że bliski kontakt człowieka z owadem potrafi burzyć spokój, czemu daje świadectwo znany entomolog Marek Kozłowski, pytając retorycznie:

Czy spojrzał ktoś w oczy mszycy lub pasikonikowi? Wystarczy użyć odpowiedniej lupy. Robiłem to wiele razy i zawsze z dziwnym uczuciem. Twarze owadów skupiają w osobliwy sposób dwie przeciwne cechy: podobieństwa i obcości ${ }^{28}$.

Być może przeczytają również, że postrzeganie rzeczywistości jest diametralnie różne od naszego - na pewno szersze - jak tłumaczy warszawski entomolog, objaśniając owadzie zwyczaje:

Żyją [...] w pełni w obcym dla nas świecie sygnałów chemicznych. Są to sygnały alarmowe, orientacyjne (np. feromony szlakowe, wyznaczające ścieżki wędrówek za pokarmem) czy socjalne, utrzymujące porządek dominacji i identyfikację gniazda ${ }^{29}$.

Co ciekawe i warte odnotowania:

Ostrość widzenia [u owadów - M.P.-L.] jest jednak kilkadziesiąt razy gorsza niż u ludzi, natomiast zdolność postrzegania zmian położenia przedmiotów (ruchu) wielokrotnie większa ${ }^{30}$.

${ }^{26}$ A. Nawarecki: O śląskiej szkole mikrologii (1999-2005). Garść wspomnień. „Forum Poetyki" 2017, nr 7, s. 13.

${ }^{27}$ W świetle tego, co mówili Derrida i dekonstrukcjoniści o kłączowości współcześnie powstających tekstów (zob. G. Deleuze, F. Guattari: Wprowadzenie: Kłącze. W: Iidem: Tysiąc plateau. Red. meryt. i językowa J. Bednarek. Tłum. S. Królak, P. Laskowski, M. Janik. Warszawa 2015, s. 13), taki model pracy z literaturą najnowszą mógłby się bardziej sprawdzić niż zazwyczaj stosowane w szkole metody strukturalne.

${ }^{28}$ M. Kozłowski: Owady Polski. Chrzaszcze. Warszawa 2009, s. 7. Podkr. - M.P.-L.

${ }^{29}$ Ibidem, s. 234.

${ }^{30}$ H. Sandner: Owady..., s. 10. 
Zatem chrząszcz, aby dostrzec sam fakt zaistnienia zmiany, musi widzieć dalej, choć ze szkodą dla ostrości postrzegania. Paradoksalność tych specyficznych zdolności polega na tym, że dla owadów zagrożenie ma charakter ogólny, a nie szczegółowy. Jeśli przyłożyć to do opowiadania, można zaryzykować postawienie tezy, że większym zagrożeniem byłby ostateczny upadek idei niż pojedynczy przypadek nieistnienia królewny ${ }^{31}$. „I pomyśleć, że w świecie platońskich idei zabrakło miejsca dla idealnych wad i nieprawości!" (s. 6). Nie ma idei fałszywości, idei błędu czy idei niedoskonałości.

Od nakreślenia linii opozycyjnej relacji „królewna-chrząszcz” łatwiejsze będzie przejście do postawionych już wyżej przeze mnie pytań o różnicę między nieistnieniem a śmiercią (dylemat: śmierć jako jeden z przejawów nieistnienia lub jako stan podległy nieistnieniu...?). Ciekawa może być dyskusja prowadzona na ten temat. Natomiast zadaniem domowym mogłoby być nadanie opowiadaniu o królewnie alternatywnego tytułu (ułożenie metafory dla całości ${ }^{32}$ ). Owa praca intelektualna uczniów ${ }^{33}$ byłaby kolejną próbą interpretacji, ale też i swoistą w prawką w poetyzowaniu, nietypowym ćwiczeniem à rebours ze stylistyki.

Klasowe obserwacje, poszerzone o wiedzę interdyscyplinarną, przyrodniczo-biologiczną, mogą przechylać interpretację utworu na różne kierunki. Ponieważ istnieje związek między nieistniejącą królewną i nieżyjącym chrząszczem, w zależności od tego, na czym (na kim) skoncentrują się odbiorcy (królewna świat makro, chrząszcz - świat mikro), zmieniać się będzie sens opowieści. Uczniowie poznają więc pewną metodę myślenia - zoom in / zoom out (przybliżanie, oddalanie jak w aparacie fotograficznym) - a tym samym odkryja działanie literatury najnowszej, niechętnie opowiadającej się po stronie jakiegokolwiek ustalonego sensu.

Ogromną szansą dla uczniowskiej recepcji opowiadania Baczewskiego, co wydaje się niezwykle ważne z punktu widzenia dydaktyki szkolnej, jest to, co stara się nazywać przywoływany na początku Kujawa:

${ }^{31} \mathrm{~W}$ opowiadaniu w ideę królewny wierzy „młodziutki paź, biedny chłopiec o jasnych włosach i oczach niebieskich jak niebo w sierpniowe popołudnie. Był on (o czym nie wiedział nikt w całym zamku) zakochany w królewnie, której nie było" (s. 13). Inną kwestią pozostaje to, że sam chłopiec zdaje się podobnym do pewnego gatunku motyla — pazia królowej — nie tylko ubarwieniem (żółto-niebieskim), lecz także owadzim stylem bycia: „Zdarzało się, że przechodził pod drzwiami jej komnaty niby to obojętnie, udając, że spieszy do swoich dworskich obowiązków, aż tu z nagła łapał za klamkę i wpadał raptownie do środka [...]" (s. 15).

32 Wspomnę jedynie, że w języku greckim metaphorá oznacza nie tylko 'przeniesienie' (M. Głowiński, T. Kostkiewiczowa, A. Okopień-Sławińska, J. Sławiński: Słownik terminów literackich. Red. J. Sławiński. Wrocław 2000, s. 300), ale także: 'przemienienie' oraz 'inne zastosowanie' (Słownik grecko-polski. T. III. Red. Z. A bramowiczówna. Warszawa 1958, s. 130).

${ }^{33} \mathrm{O}$ metaforze jako narzędziu poznania zob. G. Lakoff, M. Johnson: Metafory w naszym żyсiu. Tłum. T.P. Krzeszowski. Warszawa 1988. 
Zawierciański autor jako sprawę absolutnie priorytetową traktuje [...] spotkanie, do którego dochodzi w przestrzeni tekstu (nawet jeśli tekst ten nieraz zdaje się z czytelnika szydzić lub po prostu stawiać mu zbyt wysokie wymagania), wciąż traktuje odbiorcę jako partnera w procesie doświadczenia lekturowego ${ }^{34}$.

Zagadka śmierci żuczka i próba jej wyjaśnienia (interpretacyjne śledztwo) zarówno oswajają ,trudny” tekst, jak i służą kontemplacji wycinka rzeczywistości. Na lekcjach języka polskiego zazwyczaj czyta się fragmentarycznie, wykorzystując ułamki utworów wydrukowanych w podręczniku. Proponuję więc de facto zmianę kosmetyczną: zapoznanie się z całością danego dzieła, ale analizę tylko jego części (tutaj: sceny śmierci chrząszcza). Jedynie kontekst takiego spotkania z literaturą ewoluuje: uczeń widzi, że zajmowaliśmy się na zajęciach tylko urywkiem tekstu. Reszta Bajki pozostaje do samodzielnej refleksji. Ograniczam się do popchnięcia „ku przyjemnej samotności” ${ }^{35}$. Nie ma w tym przymusu, jest tylko zachęta. Mam również nadzieję, że takie działanie okaże się dobrym sposobem na to, by odzyskać (podtrzymać) przyjemność czytania. Być może dzisiaj jest to już nawet akcja ratunkowa, resuscytacja krążeniowo-oddechowa ${ }^{36}$, konieczna, aby nie dopuścić do postępującej martwicy serca u młodych ludzi i nauczycieli ${ }^{37}$.

\section{Bibliografia}

Boczek J.: Człowiek i owady. Warszawa 2001.

Deleuze G., Guattari F.: Wprowadzenie: Kłące. W: Iidem: Tysiąc plateau. Red. meryt. i językowa J. Bednarek. Tłum. S. Królak, P. Laskowski, M. Janik. Warszawa 2015.

${ }^{34}$ D. Kujawa: „Powiedzmy kolokwialnie, że ja z innej beczki”. Marek Krystian Emanuel Baczewski jako poeta przemilczany. W: Nie w pierwszym szeregu..., s. 20. Podkr. — M.P.-L.

35 Wykorzystuję słowa Krystyny Koziołek, które niezwykle trafnie oddają w skrócie opis tego typu doświadczeń. Zob. K. Koziołek: Czytanie z innym. Etyka. Lektura. Dydaktyka. Katowice 2006, s. 21.

${ }^{36}$ Odwołuję się w tym miejscu do diagnozy Sławomira J. Żurka: „Na lekcjach języka polskiego ustają czynności układu krążenia - uczniowie coraz słabiej mówią, piszą, nie interesują się kulturą wysoką, a także - a może przede wszystkim, bo to zdaje się główną przyczyną choroby — nie czytają, i to nie tylko klasyki" (S.J. Żurek: Jak reanimować klasykę w szkole, czyli o medycynie i czytelnictwie. W: Nowe odstony klasyki w szkole..., s. 11).

${ }^{37}$ Coraz mniej polonistów czyta (jedynie 10\%) — wynika ze wstępnych badań Żurka, przywołanych w trakcie jednej dyskusji, która toczyła się w Ośrodku Rozwoju Kompetencji Edukacyjnych. Powołuję się tutaj na relację zamieszczoną na blogu prowadzonym przez Bogusława Śliwerskiego. Zob. http://sliwerski-pedagog.blogspot.com/2014/06/osrodek-rozwoju-kompe tencji-edukacyjnych.html [data dostępu: 17.01.2018]. 
Głowiński M., Kostkiewiczowa T., Okopień-Sławińska A., Sławiński J.: Słownik terminów literackich. Red. J. Sławiński. Wrocław 2000.

Jaworek M.: Baśń, której nie było. „Bajki Baczewskiego” Marka K.E. Baczewskiego. „Inter-. Literatura - Krytyka - Kultura" 2013, nr 1.

Klimaszewski S.M.: Świat owadów. Warszawa 1973.

Kluczycki S.: Mrówki. Szesnaście pogadanek z notatek Stanisława Kluczyckiego. Kraków 1897.

Koziołek K.: Czytanie z innym. Etyka. Lektura. Dydaktyka. Katowice 2006.

Kozłowski M.: Owady Polski. Chrzaszcze. Warszawa 2009.

Kozłowski M.: Owady Polski. Warszawa 2015.

Kujawa D.: „Powiedzmy kolokwialnie, że ja z innej beczki”. Marek Krystian Emanuel Baczewski jako poeta przemilczany. W: Nie w pierwszym szeregu. O poetach lat 90. Red. T. Cieślak, T. Dalasiński. Toruń 2015.

Lak off G., Johnson M.: Metafory w naszym życiu. Tłum. T.P. Krzeszow ski. Warszawa 1988.

Miniatura i mikrologia literacka. T. 1. Red. A. Nawarecki. Katowice 2000.

Miniatura i mikrologia literacka. T. 2. Red. A. Nawarecki. Katowice 2001.

Miniatura i mikrologia literacka. T. 3. Red. A. Nawarecki, przy współudziale B. Mytych. Katowice 2003.

Nawarecki A.: Mały Mickiewicz. Studia mikrologiczne. Katowice 2003.

Nawarecki A.: O ślaskiej szkole mikrologii (1999-2005). Garść wspomnień. „Forum Poetyki” $2017, \mathrm{nr} 7$.

Nowe odstony klasyki w szkole. Red. E. Jaskółow a, K. Jędrych. Katowice 2013.

Ridley M.: O pochodzeniu cnoty. Thum. M. Koraszewska. Poznań 2000.

Sandner H.: Owady. Warszawa 1990.

Skala mikro w badaniach literackich. Red. A. Nawarecki, M. Bogdanowska. Katowice 2005.

Stownik grecko-polski. T. III. Red. Z. Abramowiczówna. Warszawa 1958.

Trzeciak K.: Buty Heideggera i wraki Kantora. O potrzebie czytania tekstów ,trudnych” w szkole. W: Doświadczenie lektury. Między krytyka literacka a dydaktyka literatury. Red. K. Biedrzycki, A. Janus-Sitarz. Kraków 2012.

Wilson E.O.: Społeczeństwa owadów. Tłum. D.H. Tymowska. Warszawa 1979.

\section{Źródła internetowe}

Blog Hodowla chrzaszczy i motyli. http://zibi.entomo.pl/hodowla_chrzaszczy.php

Być w nadziei (rozmowa z Markiem Krystianem Emanuelem Baczewskim: http://www.literaturajest sexy.pl/byc-w-nadziei-rozmowa-z-markiem-krystianem-emanuelem-baczewskim/.

Czy(m) zastąić Orzeszkową? Debata o stanie nauczania literatury współczesnej w szkołach. http://fragile.net.pl/home/czym-zastapic-orzeszkowa-debata-o-stanie-nauczania-literatury-wspolczesnej-w-szkolach/.

Podstawa programowa - język polski - szkoła podstawowa - klasy IV - VIII. Załącznik nr 2 do Rozporzadzenia MEN z 14.02.2017 r. w sprawie podstawy programowej wychowania przedszkolnego oraz podstawy programowej ksztatcenia ogólnego dla szkoty podstawowej, w tym dla uczniów z niepetnosprawnościq intelektualna $w$ stopniu umiarkowanym lub znacznym, kształcenia ogólnego dla branżowej szkoły I stopnia, kształcenia ogólnego dla szkoły specjalnej przysposabiajacej do pracy oraz ksztatcenia ogólnego dla szkoły policealnej. https:// men.gov.pl/wp-content/uploads/2016/11/podstawa-programowa-\%E2\%80\%93-jezyk-polski-\%E2\%80\%93-szkola-podstawowa-\%E2\%80\%93-klasy-iv-viii-.pdf. 
Podstawa programowa ksztatcenia ogólnego dla czteroletniego liceum ogólnoksztatcacego i pięcioletniego technikum. Załącznik nr 1 do Rozporządzenia MEN z 30.01.2018 r. w sprawie podstawy programowej ksztatcenia ogólnego dla liceum ogólnoksztatcacego, technikum oraz branżowej szkoty II stopnia, wchodzące w życie 1.09.2019 r. https://men.gov.pl/wp-content/ uploads/2018/01/zalacznik-nr-1.pdf. 